\title{
Web-based Learning Environments: Do Libraries Matter?
}

\section{Donald Beagle}

\begin{abstract}
Web-based learning environments are becoming more widely used for on-campus and distance education course delivery. A review of articles on the topic by faculty shows that only a few mention issues related to library access or resource integration. Moreover, only a small number of courseware evaluations posted on academic Web sites include criteria related to libraries. However, a few articles and reviews share common themes that point to a greater library involvement in courseware implementation, which is consistent with arguments made by distance education librarians calling for an active role in technical, pedagogical, and instructional support decisions concerning Web-based learning environments.
\end{abstract}

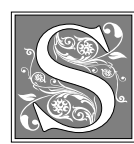

ince the creation of the World Wide Web, its potential as an instructional tool and learning environment has attracted intense academic interest and commercial development. Tim Berners-Lee, who originated the Web while working at the European Organization for Nuclear Research (CERN), identified Web-based education as one of four major areas that (1) are driving commercial participation in the World Wide Web Consortium (W3C), (2) are providing consensus on protocols that allow new applications to speak the same language, and (3) collectively are becoming "key to the development of the Web." 1

This convergence of academic interest and commercial development has led to the creation and marketing of software packages variously termed Web-based courseware, Web-based learning environments, and in distributed extensible form, asynchronous learning networks (ALNs).
These products arrive at a time when colleges and universities are under growing pressure to undertake new or expanded distance education initiatives. But as Webbased courses have been implemented, another trend has been noted, namely that significant numbers of students enrolled on campus are seeking to participate in them. Thus, Web-based learning environments have broken out of the distancelearning milieu and are becoming part of the larger academic agenda. "Online courses are offered to both on-campus and distance-learning students, on-campus faculty are creating World Wide Web pages with course materials, and e-mail is ubiquitous. The lines between on and off-campus students and courses are indeed blurring as technology is incorporated into all aspects of education." ${ }^{2}$

The ongoing parallel migration of library catalogs, database gateways, and full-text resources to the Web would seem to offer libraries opportunities to re- 
think-and perhaps redefine-their role in this rapidly evolving academic enterprise. This article is an attempt to review the still-nascent literature on Web-based learning environments to gather evidence applicable to the following interrelated questions:

1. As faculty and administrators publish articles on the theoretical or practical aspects of Web-based courseware in colleges and universities, to what degree do they include discussion of library support activities, resource access, or integration of library systems and tools?

2. As universities document their evaluation of competing Web courseware development packages, to what degree do library support issues play a discernible role in the evaluation and selection process? Does compatibility with, integration of, or access to library systems and resources play a role in actual purchasing decisions?

3. For those articles and evaluation reports that include library issues, do any address the topic in a particularly insightful way? Do these exemplars share any common viewpoints about library resource access or system integration that make them models for the rest of the academic community?

4. As librarians themselves publish articles on ALNs, to what degree do their observations appear to agree or disagree with views expressed by faculty? Taking these articles as a thematic whole, what sort of role do the authors advocate or predict for libraries in Web-based learning environments?

\section{Summary of Findings}

A survey of articles published by faculty and administrators in a leading ALN journal on any aspect of Webbased courseware in colleges and universities indicates that only about 10 percent discuss libraries in more than a marginal or tangential way. A sampling survey of courseware evaluation reports issued by colleges and universities and posted on academic Web sites similarly indicates that only about 10 percent include any criteria related to library system compatibility or resource accessibility in their evaluation and purchasing decisions.

However, among the few articles and evaluation reports that do address library-related issues, the author has found that several treat the issues in an insightful way. Moreover, these exemplars appear to share certain underlying assumptions and elements of vision that could contribute to an enhanced role for libraries in the design of ALNs in the future.

Lastly, a sampling of articles published by librarians on the subject of asynchronous learning provides evidence of common themes that appear to share significant features with the viewpoints expressed by the exemplars mentioned above. Taken together, these thematic similarities may offer a strategy for libraries to play a larger role in the development of Web-based learning environments.

\section{Literature Review, Part 1}

All full-text articles published in the Journal of Asynchronous Learning Networks $(J A L N)$ since its inception in 1997 were searched for the words library and libraries. Of the thirty-six articles searched, fourteen (about $40 \%$ ) included at least one mention of one or both words. One article specifically addressed library issues as its principal topic, and three others treated it in a qualitatively different way from the other ten. As a quantitative check to ensure that JALN does not underrepresent literature related to libraries, the author ran similar searches against online abstracts, titles, or content summaries for a number of journals also active in ALN publishing. Active Learning, published by the Computers in Teaching Initiative, returned two hits for ten issues since $1995 .{ }^{3}$ Computer-Mediated Communications Magazine returned no hits for fortynine issues published between 1995 and 1999. ${ }^{4}$ The Journal of Computer-Assisted Learning returned no hits for twenty issues searched between 1995 and 1999. ${ }^{5}$ No hits were registered for a search against twenty issues of the Journal of Technology 
Education. ${ }^{6}$ Finally, The Online Chronicle of Distance Education and Communication_returned five hits for nineteen (full-text) articles. ${ }^{7}$ Although full-text searches of all the articles in these journals were beyond the scope of this study, the results for title, summary, and abstract searches suggest that $J A L N$ is a reasonably representative source for measuring the level of scholarly discussion regarding libraries and Web-based learning.

An overview of the ten JALN articles making marginal reference to libraries produced a number of responses. According to an article by J. R. Bourne, A. J. Broderson, and J. O. Campbell, traditional libraries will likely be replaced by digital libraries providing online resources in addition to course materials. ${ }^{8}$ In another article, William H. Graves asserted that both libraries and information technology support organizations face rising demand, greater costs, and the need to change or abandon certain key services in response to changes brought about by digital technologies. ${ }^{9}$ In describing the cost structure of a virtual university, Murray Turoff argued that although the virtual university may lack an outstanding library, many traditional college libraries face budget cuts or constraints "so that they do not provide collections that are any better than what might be expected to become available in the future on CD-ROM and over the net .... One could create a set of CD-ROMs filled with all the material needed for a particular degree and pay appropriate royalties for limited distribution of the material."10 John R. Bourne, Eric McMaster, Jennifer Rieger, and J. Olin Campbell discussed ALN courses from the perspective of various learning paradigms. Under the paradigm of "discovery learning," they contrasted traditional discovery learning (characterized by "library, literature searches") with ALN discovery learning (characterized by "Web searching") and concluded, with no supporting documentation, that "Web searches are often much better than traditional library searching." 11 In an article reviewing a series of emerging organizational models for sponsorship of Web-based learning, Donald E. Hanna found that access to specific documents and resources appropriate to the individual program typify alternative models as contrasted with access to "volumes in the library" found in traditional academic models. ${ }^{12}$ Mary Beth Almeda reviewed the University of California Extension Online services and noted their use of a software tool called "Public Library," which she described as "a resource area available to all browsers which includes materials and Internet sites selected for various courses. Prospective students who browse a particular article or Internet reference are reminded of the course or courses to which those materials are pertinent."13 Mary Graham briefly referred to "a prototype text-based menu interface to provide dial in or network access to e-mail, bulletin boards, the Library catalogue and an online book request service."14 Robert N. Diotalevi touched on reservations expressed in the library community about the Digital Millennium Copyright Act. ${ }^{15}$ In yet another article, Mark H. Rossman mentioned that the standard format for all online courses at Capella University includes library assignments, though no detail is given on how access to or integration of library resources is provided in relation to those assignments. ${ }^{16}$ And finally, Juan R. Pimental suggested that although libraries may be a component of effective learning environments for many subjects, they do not figure in his discussion of online experiential learning models for engineering students. ${ }^{17}$

The authors of four other articles made comments that are qualitatively different from the ten cited above because they discuss the pertinent library questions with remarks that make the case for library involvement in ALN's going beyond individual course requirements to a student's total educational experience. James J. Duderstadt presented a challenging vision of the university as a "knowledge server" for an information-based economy and identified the library as the 
intellectual focal point of a digital convergence of a wide range of media. He described the role of the library as becoming more of a knowledge navigator and a facilitator of retrieval and dissemination. ${ }^{18}$ Ian C. Reid described a comprehensive university strategy for online instruction, built on a custom-designed ALN. He related the integration of online forms of student support, including library services, to the total range of components that make up a student's experience of a subject. And he specifically stated that in the production of extensible and interoperable system components for the course network, a team of information technology specialists must work to ensure that "Library support is linked into the templates developed, so this can appear automatically for all materials." ${ }^{\prime 19}$ In her review of the Penn State World Campus, Melody M. Thompson stressed the importance of "Connectedness to a larger learning context .... World Campus courses provide course-specific and disciplinary electronic links to libraries and other data collections that offer students access to vast collections of information. From these and other sources students can gather the raw materials they need to develop a personal knowledge base and a coherent approach to their program of study." 20

\section{A sampling of thirty-two docu- mented evaluations was retrieved and reviewed, noting any mention of criteria related to libraries, electronic resources, or online catalogs.}

In the one $J A L N$ article specifically addressing the topic, Joanne Eustice and Gail McMillan noted that as asynchronous learning becomes the norm throughout academia, academic libraries have little choice but to change dramatically. Although libraries have a history of aggressively adapting new technologies, they have been slow to adjust organizational structures and processes to leverage their potential. However, new patterns are emerging relative to resource reallocation and the formation of partnerships with other university units that reflect new priorities. $^{21}$

Viewed as a group, the articles in JALN and similar online journals present a discouraging statistical picture for advocates of active library involvement in Webbased learning environments. The majority of articles do not mention libraries. Of those that do, most mention library resources in a marginal or tangential manner. Only four make a case, however briefly, for active library support and involvement in ALNs, and only one does so as a principal topic. However, the four mentioned here do share a particular approach to the subject, which, when viewed in the context of research on student and faculty attitudes toward library use in distance education, may provide a possible interpretation.

\section{Interpretation}

In a survey of a thousand students and faculty participating in distance education courses in the United Kingdom, Kate Stephens and Lorna Unwin discovered "a significant mismatch of expectations between students and course providers about the role of libraries in the distance learning mode." ${ }^{22}$ Faculty either viewed the problem as irrelevant to their students or saw problems in their own institutional arrangements. Students, on the other hand, when asked whether they felt the need to supplement course material with additional reading, responded affirmatively, with 78 percent indicating that they needed to do so "to some extent," "quite a lot," or "a great deal." Stephens and Unwin also described a two-pronged typology of distance education courses: Type A: The self-contained course, where students study from an assembled package of materials designed to provide all necessary and expected reading and research sources; and Type B: The expandable package, where students study largely from packaged materials, but wider reading would be recommended. Type A course providers justified their approach based on equity (some students may not have 
access to libraries) or the notion that they, the academics, should set the boundaries of study by choosing all necessary sources. Type B course providers recognized the issue of equity and accepted that some students would only study from the supplied materials but also believed that students should develop their skills as autonomous learners. In both types of courses, however, it seems that the majority of students wish to transcend the reductionist approach of their instructors.

The survey of $J A L N$ articles may reveal a similar dichotomy. Many authors may not mention-or barely mention-libraries as a result of a reductionist tradition that assumes reliance on prepackaged, self-contained resources, as opposed to a smaller expansionist group looking beyond the constraints of that tradition to the broader potential of distributed access to Web-based learning environments in which libraries play an active interpretive or facilitative role. This reading of the article survey is supported by comments in the former group that describe "access to specific documents and resources appropriate to the individual program," as contrasted with the latter group whose remarks emphasize "Connectedness to a larger learning context" and "the total range of components which make up a student's experience of a subject." From this perspective, advocates of library support and involvement can claim, as Eustice and McMillan did, that the digital environment is a natural medium for those libraries that have blazed a technological trail now being followed by other segments of the academic community.

\section{Courseware Evaluation Reviews}

The theoretical and practical content of $J A L N$ articles forms a backdrop to the second part of this study, which examines online documentation of evaluations on the part of college and university review bodies. To unearth a sampling, the author utilized two major search engines (Hotbot, Northern Light) using the names of prominent Web courseware products paired with the terms evaluation and se- lection. A sampling of thirty-two documented evaluations was retrieved and reviewed, noting any mention of criteria related to libraries, electronic resources, or online catalogs. Some of the evaluations were articles or presentation papers by individual reviewers, some were committee or task force reports, some were raw spreadsheets or checklists correlating criteria and vendors, and a few were combinations of the above. ${ }^{23-26}$ Only three of the thirty-two evaluations made any mention whatsoever of access to or integration of library resources as criteria for selection..$^{27,28}$ For at least the initial wave of ALN implementation, this would seem to suggest that the reductionist viewpoint has prevailed and that to a certain extent libraries have been marginalized.

A less severe argument could be made as follows: As libraries migrate their online catalogs, database gateways, and associated retrieval tools to the Web, their compatibility with any and all potential Web-based learning environments may simply be taken for granted by faculty and administrators. University evaluation committees may come to the table assuming that issues of library resource access or integration would not be revealing as comparative or evaluative criteria. However, none of the evaluation reports includes statements to this effect or mentions any initial assumptions about library resources or systems. Within the framework of the current study, this question cannot be firmly resolved. But if such assumptions about libraries are indeed being made, the exemplar evaluation review carried out by the University of Minnesota suggests that those assumptions may not be valid.

Under the auspices of its Digital Media Center, the University of Minnesota conducted a detailed comparison of four courseware development products: Academos, ClassWeb, TopClass, and WebCT. ${ }^{29}$ One section of its evaluation study, entitled "Access to Centralized Resources for Teaching and Learning," looks beyond distance education to the larger institutional context: 
Web-assistance for courses can serve to break down the artificial boundaries between the "physical" space of the classroom and all of the outof-class materials that go into constituting students experiences in college ... course websites can provide a convenient means for breaking down some of the physical and temporal boundaries of the classroom by permitting integrated access to these resources when and where students need it most by linking to resource sites or using learning-support tools like the University Libraries' Research QuickStudy/ QuickStart to develop customized assignments for students. In this section, we asked our respondents to rate their tools' performance in providing access to these centralized resources. For the purpose of this report, "central resources" refers to University-wide learning resources (like the University Libraries' online databases, tutorial and learner-support services available online, and others), not central administrative services. $^{30}$

The study found significant differences in vendor responses to their inquiry. Only one developer responded that it offered an architecture that allows users to open pop-up windows to central resources such as the university libraries without leaving the courseware environment and without intervening authentication. By contrast, the other vendors replied that sharing resources or linking to outside resources may require users to pass back and forth through security firewalls (again, meaning in some cases having to authenticate multiple times within a single session). One indicated the need for a discreet library links page rather than using integrated links within class content, and another noted the need for workarounds when students had to leave the class environment to pass through authentication multiple times in the same session.
Interestingly, the Minnesota study coupled its question about library resource access for students with one about faculty access to pedagogical/class development aids developed by its Center for Teaching and Learning (a linkage that reappears later in remarks about pedagogical collaboration between librarians and faculty). Again, only one vendor indicated that it had provided functional access to class development aids such as a syllabus-design tutorial and pedagogical aids such as information technology literacy tutorials, in addition to access to library databases and finding aids. It also indicated collaboration with the University's Writing Support Network. The other three course vendors were reported to have responded no to the question about integration of pedagogical and class development aids.

It should be pointed out that two of the reviewed products were developed inhouse by units of the University of Minnesota, so that only two leading external marketplace vendors of courseware were included in this review. (All four systems were being used by various units of the University of Minnesota, which, in fact, facilitated this unusually thorough review.) However, it is instructive to note that the attention given to central resource integration from the university library and the Center for Teaching and Learning parallels the findings of Reid in $J A L N$, who described the integration of library resource links in templates for a custom ALN as being a key part of a comprehensive university strategy for online instruction. The implication is that library system access and integration is a function that has been carried out more aggressively and effectively in custom-designed environments than in commercially available Web courseware packages.

Given their apparent lack of participation in the majority of courseware evaluation processes sampled, it would seem that academic librarians face a choice if they wish to be players in the formation of enhanced Web-based learning environments in the future. They may argue for the development of customized environ- 
ments that follow the example of Reid's article and the Minnesota study or they may need to bring pressure to bear on commercial vendors (perhaps through professional associations) to enhance courseware tools and modules for more effective centralized resource access and integration.

The question goes beyond the narrow convenience issue of student authentication or firewall pass-through. The visions expressed by Duderstadt, Reid, Thompson, and others will be shown to parallel arguments made in the library literature that librarians must play a more active instructional, technical, and pedagogical role in Web-based learning environments through a variety of venues such as online bibliographic instruction, information literacy, extended OPACs, and enhanced user interfaces. But those potential roles may be difficult to fulfill if courseware development remains constrained within a reductionist tradition. How librarians are responding in the literature, to both the hopes of expansionists and the threats of reductionists, forms the third part of this study.

\section{Literature Review, Part 2}

The author found no peer-reviewed library journal specifically focused on Webbased learning environments. For representative views expressed by librarians on the subject of asynchronous learning programs including Web-based environments, the author reviewed all articles published in the Journal of Library Services for Distance Education (JLSDE) since its inception in 1997. Alternative journals with articles relating libraries to ALNs would, of course, include MC Journal: The Journal of Academic Media Librarianship, Ariadne, and D-Lib Magazine. ${ }^{31-33}$ A scan of pertinent titles in MC Journal revealed a number articles by contributors to $J L S D E$, lending credence to the latter as a representative sampling of published views.

The articles in JLSDE include case studies, position statements, model building, and calls for action. Although they repre- sent a variety of institutions and experiences, the author sees thematic and polemic correlations emerging from the group. These correlations are paraphrased with examples and variations as follows:

1. Librarians must play an enhanced instructional role, for both students and faculty. Emphasis was placed on use of the Web to refocus library instruction on the needs of individual students rather than classroom groups. This is seen as paralleling the new focus on a learner-centered environment for Web-based courseware in general.

Thomas E. Abbott identified education of faculty and students in the access, evaluation, and application of information from the Internet as the single most valuable service librarians can offer. He stressed use of the Web for this training as a means of distributing access among multiple campuses and thousands of independent learners. ${ }^{34}$ Chris Adams emphasized instructional development as key to the creative integration of library services into technology initiatives. ${ }^{35}$ Donald Beagle argued that extended bibliographic instruction packages should be developed hand in hand with general courseware creation and pointed out that the Web allows on-demand, just-in-time access for students throughout the academic term. ${ }^{36}$ Debbie Orr and Margaret Appleton stressed that library teaching programs should go beyond practical skills to include critical thinking abilities needed by students trying to navigate the expanding array of resources. They noted a survey of students showing that computer-assisted instruction that offered interactive, selfpaced learning was preferred over traditional classroom bibliographic instruction. ${ }^{37}$ Sarah Ashton proposed development of formal networked learner support (NLS) activities encompassing online approaches to user education, information skills training, reference assistance, electronic mail, asynchronous conferencing, real-time chat, multi-user environments, and video-conferencing. ${ }^{38}$ Carol Goodson explored the use of technology to customize services for individual users, arguing that this should become the norm, rather 
than the exception, for all library services. ${ }^{39}$ Laura Davidson noted that the self-paced instruction allowed by Web-based tutorials fits the persona of the off-campus student. ${ }^{40}$

2. Many authors stressed the importance of active collaboration between librarians and teaching faculty on a pedagogical design for better integration of library resources with course content. Several authors went beyond this to call for ongoing three-way collaboration among librarians, teaching faculty, and IT training and support staff.

Abbott made the case for faculty working with "companion" librarians to create information management learning opportunities in their courses. ${ }^{41}$ Ashton remarked that as librarians begin to use the Web and other networked technologies, they should work more closely with academic staff to provide support for resource-based learning approaches and to embed opportunities for information-related skills development more securely into the learning experience. She also pointed out that librarians will benefit from a better understanding of the pedagogic environment that faculty work within and from greater knowledge of the many ways people can use the network as a learning medium. This is seen as helping the librarians move beyond rudimentary lists of linked resources to an instructional program that is more dynamic for learners. ${ }^{42}$ Orr and Appleton also discussed the need for librarians to go beyond using the Web to mount electronic copies of printed subject guides that do not provide interactive instruction or assist the user to acquire the skills to fully utilize the sources. ${ }^{43}$ Gloria Lebowitz wanted librarians to take a more open and proactive role in the educational process to help faculty develop assignments that are feasible in the electronic environment. ${ }^{44}$ Holly Heller-Ross referred to a similar process as course curriculum enrichment that "necessarily precedes and improves collaborations by library and faculty to offer students research activities that advance their academic subject mastery and their ability to apply new information to their work." 45 Stephens and Unwin hope to encourage faculty to confront the relationship between libraries and networked learning, to reassess their approach to the design and delivery of courses, and to open their eyes to the underused potential of librarians. "We envision a more hopeful and exciting future, in which academics and librarians collaborate to expand the pedagogical boundaries of distance learning, ensuring that electronic developments are integrated with traditional concerns for wide reading, student autonomy and independent thinking." 46

3. Technical collaboration between systems librarians and campus IT staff also was a topic of discussion in order to facilitate the functional integration of library resources and Web courseware on the operational level. Consolidation of libraries and computing services staff is viewed as a potential consequence.

Maryhelen Jones predicted a trend toward frequent, sustained collaboration with instructional and technical teams responsible for designing and delivering networked courses ${ }^{47}$ Cesar Caballero and Henry T. Ingle described a three-way model to expand teaching partnerships among librarians, faculty, and computer technologists. ${ }^{48}$ Kitti Caneppi found advantages to identifying and contacting innovators and early adopters among faculty, researchers, and technology support staff. ${ }^{49}$ Judith Clark and Ron Store suggested that for such partnerships to succeed, librarians need to view themselves as part of the teaching and research endeavor and to participate as active and integral peers within the education team. ${ }^{50}$ Angela Lee found that because customization of library resources to networked classes can be time-consuming and costly, the library must learn to anticipate the demands of the curriculum and should take the lead in coordinating services. ${ }^{51}$ Beagle urged librarians to contribute to the design of a learning technology base that offers greater flexibility for teachers and students, including a greater degree of functional integration with the library's online system..$^{52}$ Heller-Ross ex- 
pected to see libraries merging with computing and technology centers to facilitate the use of information and technology at their institutions..$^{53}$ Ashton felt that we are witnessing the consolidation of library, computing, and academic roles, with opportunities for information professionals to make an important contribution to designing and supporting rich environments for networked learning. ${ }^{54}$

4. Institutional cooperation between academic and public libraries is emphasized for distance-learning applications of ALNs, as is the need for carefully formulated consortial and resource-sharing arrangements. A number of authors speculated on the need for outsourcing and cooperation with profit-centered education and training enterprises.

Adams said that a growing number of cooperative ventures with other academic institutions will be driven politically and financially as libraries of all kinds make agreements to underwrite the high cost of technology-oriented services. ${ }^{55}$ Peter Brophy agreed and speculated that "we may even see the long-overdue destruction of barriers between academic and public libraries." 56 Jones pointed out that because higher education's institutional framework is changing due in part to the versatility and perceived economy of networked learning, our most important future professional alliances may be with corporate virtual universities. ${ }^{57}$ Marie Kascus pointed to the advantage of statewide consortia as the impetus for an emerging kaleidoscope of options for learners, including full-text retrieval, seamless document delivery from publisher to workstation, online reference service, and electronic communication. ${ }^{58}$ Lee argued that because networked learning facilitates a decentralized form of access to higher education, its very success depends on wide community support and cooperation. This implies that the networked learning environment must include the active participation of libraries at all levels-universities, community colleges, schools, public libraries, etc.to ensure the delivery of information and services to a dispersed clientele. ${ }^{59}$
5. A renewed need for internal team-based organizational structures was identified by a number of authors, especially for selection and implementation of electronic resources and coordination of instructional activities.

Caballero and Ingle, for example, made the case for a team-based approach to electronic resource management as opposed to centering all responsibility on a single individual in a Reference or Information Services Department. Building on cited articles about a systems concept for information delivery, they described an electronic resource team consisting of an electronic resources coordination librarian and representatives from Library Systems, Public Services, Technical Services, plus subject specialists (as needed). ${ }^{60}$ HellerRoss proposed a similar model, emphasizing instructional activities built around an Instructional Services Group. "The advantages of an integrated and distributed model include the focus provided by the designated librarian and the diversity of ideas and skills provided by the participation of all other library faculty and staff. The structure creates opportunities to pilot and adopt innovative approaches and test new procedures on a smaller patron group, while quickly responding to new options and patron concerns." 61

6. A need for greater awareness of economic and marketplace issues was discussed frequently, with examples being the increased competitiveness of the educational landscape and the budgetary constraints imposed on libraries.

Abbot advocated a role for librarians in the future as educational entrepreneurs, seeking and organizing information and training students in the new life skills required for effective information management. ${ }^{62}$ Brophy equated the growing modularization of courses with opportunities for nonsequential learning, a new concern with building a learning society and an information economy, and stated that the experience of telecommunications and Internet service providers looking for new markets all point in the same direction. Learning will take place in chunks throughout life, at the learner's 
convenience (time, place, style, etc.) and across a variety of providers. ${ }^{63}$ Tony Cavanaugh suggested that the supplying of library services will become highly competitive. "In the best tradition of economic rationalism, librarians will need to consider profit margins, performance standards, benchmarking, etc. They also need to acquire a much clearer idea of the true cost of services. I have little doubt that the successful libraries of the future will be the ones that are best able to combine quality with efficiency in delivery of services." ${ }^{64}$ And Jones predicted that vendors offering electronic access and/or digitized content will increasingly seek the expertise of librarians as they try to tap the market potential of networked learning. ${ }^{65}$

\section{Librarians currently providing support for asynchronous learning environments argue that their experiences should be seen as a bellwether for all library services in the future.}

7. Librarians expressed a number of recurring fears and concerns about this brave new world of Web-based learning, many of which relate to the broad issue of library marginalization described earlier as well as economic pressures of a newly competitive marketplace.

Adams expressed concern that the prevalent thinking of tomorrow will be that the library can absorb demands for materials and service for these new programs because they are already doing so for traditional users. If so, then library services to networked learners will remain reactionary and overly traditional. ${ }^{66}$ Alexander L. Slade explored the possibility that students will be assumed to be less dependent on libraries as they become able to conduct literature searches from their homes or offices through the Internet or use commercial document suppliers to obtain selected periodical articles. ${ }^{67}$ Stephens and Unwin argued that unless libraries are encouraged to play a central role in the learning process and are supported in that effort, networked learners will face an environment in which their experiences are tightly bounded and controlled. "We are skeptical that advances in technology will necessarily help distance learners become more autonomous, and fearful that electronic access might compound the trend towards narrowly prescribed reading, leading to even greater student isolation as teachers are pushed further into becoming designers of pre-packaged programmed learning." ${ }^{\prime 68}$ Ashton identified "skills gaps" in the areas of information technology, the use and evaluation of networked information resources, and educational applications of the networked environment, as well as deficiencies of expertise in cross-disciplinary team work and the management of change and innovation. ${ }^{69}$ Clark and Store expressed concern that unless information resource and library support provisions are not placed higher on the academic agenda, it may become more difficult legally, technically, and economically to deliver library support than to deliver curriculum and content. ${ }^{70}$

\section{Conclusion}

Web-based learning environments have emerged from a distance education tradition that, one study indicated, exhibits a tendency to assume minimal access to library services. The result is a reductionist practice of providing all expected resource material in an instructional package. Although web-based courseware also is being used by on-campus students who have wider expectations of library support, a sampling of published articles on ALNs by faculty and administrators indicates a continuing assumption of minimal library involvement and access. This is reinforced by a sampling of evaluation reviews of commercial courseware providers, in which library issues play only a marginal role. However, a small number of articles and evaluation reviews reveal another line of expansionist thinking that looks beyond the constraints of that tradition to the broader potential of distributed access to 
Web-based learning environments where libraries play an active interpretive or facilitative role. This viewpoint is more apparent in a sampling of library literature, where authors have proposed greater collaboration and participation in the instructional design and delivery process.

Many articles in JALN and similar journals express the strong belief that use of Web-based learning environments will continue to increase in the future until they become ubiquitous, and many authors expect that the result could be major structural changes in our culture's educational delivery system. That libraries should be marginalized during the onset of such a potentially transformative process is disturbing. Librarians currently providing support for asynchronous learning environments argue that their experiences should be seen as a bellwether for all library services in the future. The question remains whether the larger library and academic communities are listening.

\section{Notes}

1. Tim Berners-Lee, "Realizing the Full Potential of the Web." Accessed Feb 1, 2000, www.w3.org/1998/02/Potential.html .

2. Holly Heller-Ross, "Library Support for Distance Learning Programs: A Distributed Model," Journal of Library Services for Distance Education 2, no. 1 (July 1999). Accessed Feb. 1, 2000, www.westga.edu/ library/jlsde/jlsde2.1.html.

3. Active Learning. Accessed February 1, 2000, www.cti.ac.uk/.

4. Computer-Mediated Communication Magazine. Accessed Feb. 1, 2000, www.december.com/ $\mathrm{cmc} / \mathrm{mag} /$ current/toc.html.

5. Journal of Computer-Assisted Learning. Accessed Feb. 1, 2000, www.lancs.ac.uk/users/ktru/ jcaljrnl.htm.

6. Journal of Technology Education. Accessed Feb. 1, 2000, http:/ / scholar.lib.vt.edu/ejournals/ JTE/jte.html.

7. The Online Chronicle of Distance Education and Communication. Accessed Feb. 1, 2000, www.fcae.nova.edu/disted/.

8. J. R. Bourne, A. J. Broderson, and J. O. Campbell, "A Model for On-Line Learning Networks in Engineering Education," Journal of Asynchronous Learning Networks 1, no. 1 (Mar. 1997). Accessed Feb. 1, 2000, www.aln.org/alnweb/journal/issue1/bourne.htm.

9. William H. Graves, "Free Trade in Higher Education: The Meta University," Journal of Asynchronous Learning Networks 1, no. 1 (Mar. 1997). Accessed Feb. 1, 2000, www.aln.org/alnweb/ journal/issue1/graves.htm.

10. Murray Turoff, "Costs for the Development of a Virtual University," Journal of Asynchronous Learning Networks 1, no. 1 (Mar. 1997). Accessed Feb. 1, 2000, www.aln.org/alnweb/journal/issue1/turoff.htm.

11. John R. Bourne, Eric McMaster, Jennifer Rieger, and J. Olin Campbell, “Paradigms for OnLine Learning: A Case Study in the Design and Implementation of an Asynchronous Learning Networks (ALN) Course," Journal of Asynchronous Learning Networks 1, no. 2 (Aug. 1997). Accessed Feb. 1, 2000, www.aln.org/alnweb/journal/issue2/assee.htm.

12. Donald E. Hanna, "Higher Education in an Era of Digital Competition: Emerging Organizational Models," Journal of Asynchronous Learning Networks 1, no. 2 (Aug. 1997). Accessed Feb. 1, 2000, www.aln.org/alnweb/journal/vol2_issue1/hanna.htm.

13. Mary Beth Almeda, "University of California Extension Online: From Concept to Reality," Journal of Asynchronous Learning Networks 2, no. 2 (Sept. 1998). Accessed Feb. 1, 2000, www.aln.org/alnweb/journal/vol2_issue2/almeda.htm.

14. Mary Graham, "Implementing Computer Mediated Communication in an Undergraduate Course-A Practical Experience," Journal of Asynchronous Learning Networks 3, no. 1 (May 1999). Accessed Feb. 1, 2000, www.aln.org/alnweb/journal/Vol3_issue1/graham.htm.

15. Robert N. Diotalevi, "Copyright Dot Com: The Digital Millennium in Copyright," Journal of Asynchronous Learning Networks 3, no. 2 (Nov. 1999). Accessed Feb. 1, 2000, www.aln.org/ alnweb/journal/Vol3_issue2/diotalevi.htm.

16. Mark H. Rossman, "Successful Online Teaching Using an Asynchronous Learner Discussion Forum," Journal of Asynchronous Learning Networks 3, no. 2 (Nov. 1999). Accessed Feb. 1, 2000, www.aln.org/alnweb/journal/Vol3_issue2/Rossman.htm.

17. Juan R. Pimentel, "Design of Net-learning Systems Based on Experiential Learning," Journal of Asynchronous Learning Networks 3, no. 2 (Nov. 1999). Accessed Feb. 1, 2000, www.aln.org/ alnweb/journal/Vol3_issue2/pimentel.htm. 
18. James J. Duderstadt, "The Future of the University in an Age of Knowledge," Journal of Asynchronous Learning Networks 1, no. 2 (Aug. 1997). Accessed Feb. 1,2000, www.aln.org/alnweb/ journal/issue2/duderstadt.htm.

19. Ian C. Reid, "Beyond Models: Developing a University Strategy for Online Instruction," Journal of Asynchronous Learning Networks 3, no. 1 (May 1999). Accessed Feb. 1, 2000, www.aln.org/ alnweb/journal/Vol3_issue1/reid.htm.

20. Melody M. Thompson, "Using ALNs to Support a Complete Educational Experience," Journal of Asynchronous Learning Networks 3, no. 2 (Nov. 1999). Accessed Feb. 1, 2000, www.aln.org/ alnweb/journal/Vol3_issue2/Thompson.htm.

21. Joanne Eustis and Gail McMillan, "Libraries Address the Challenges of Asynchronous Learning," Journal of Asynchronous Learning Networks 2, no. 1 (Mar. 1998). Accessed Feb. 1, 2000, www.aln.org/alnweb/journal/vol2_issue1/eustis.htm.

22. Kate Stephens and Lorna Unwin, "The Heart of the Matter: Libraries, Distance Education and Independent Thinking," Journal of Library Services for Distance Education 1, no. 1 (Aug. 1997). Accessed Feb. 1, 2000, www.westga.edu/ library/jlsde/jlsde1.1.html.

23. Sunil Hazari, "Evaluation and Selection of Web Course Management Tools." Accessed Feb. 1, 2000, http://sunil.umd.edu/webct/.

24. "Web Course Tool Selection Committee Report." Accessed Feb. 1, 2000, www.utexas.edu/ $\mathrm{cc} / \mathrm{cit} /$ tools/index.html.

25. "Web-based Educational Environments: Comparison of Software Features." Accessed Feb. 1, 2000, http://isis.acomp.usf.edu/Web-Based/comparison.html.

26. Bruce Landon, "Online Educational Delivery Applications: A Web Tool for Comparative Analysis." Accessed Feb. 1, 2000, www.ctt.bc.ca/landonline/.

27. "Comparison of Online Course Delivery Software Products." Accessed Feb. 1, 2000, http:/ /multimedia.marshall.edu/cit/webct/compare/comparison.html.

28. "Comparison of On-line Education Systems." Accessed Feb. 1, 2000, www.spu.edu/ $\sim$ dwicks/comparison.htm.

29. "Web-based Authoring Tools Comparison Report." Accessed Feb. 1, 2000, www1.umn.edu/ $\mathrm{dmc/portfolio/comparison/index.shtml.}$

30. "Comparative Evaluation: Access to Centralized Resources Learning for Teaching and Learning." Accessed Feb. 1, 2000, www1.umn.edu/dmc/portfolio/comparison/access.shtml.

31. MC Journal: Journal of Academic Media Librarianship, http://wings.buffalo.edu/publications/mcjrnl/curriss.html.

32. Ariadne, www.ariadne.ac.uk/.

33. D-Lib Magazine, www.dlib.org/dlib/january00/01contents.html.

34. Thomas E. Abbott, "Maine College Cyber-Programs Offered Internationally," Journal of Library Services for Distance Education 1, no. 1 (Aug. 1997). Accessed Feb. 1, 2000, www.westga.edu/ - library/jlsde/jlsde1.1.html.

35. Chris Adams, "The Future of Library Services for Distance Education: What Are We Doing, Where Are We Heading, What Should We Be Doing?" Journal of Library Services for Distance Education 1, no. 1 (Aug. 1997). Accessed Feb. 1, 2000, www.westga.edu/ library/jlsde/ jlsde1.1.html.

36. Donald Beagle, "Asynchronous Delivery Support for Distance Learning: A Strategic Opportunity for Libraries," Journal of Library Services for Distance Education 1, no. 2 (June 1998). Accessed Feb. 1, 2000, www.westga.edu/ library/jlsde/jlsde1.2.html.

37. Debbie Orr and Margaret Appleton, "New Opportunities for Remote Students," Journal of Library Services for Distance Education 1, no. 1 (Aug. 1997). Accessed Feb. 1, 2000, www.westga.edu/ library/jlsde/jlsde1.1.html.

38. Sarah Ashton, "Piloting Online Professional Development for Networked Learner Support," Journal of Library Services for Distance Education 1, no. 2 (June 1998). Accessed Feb. 1, 2000, www.westga.edu/ library/jlsde/jlsde1.2.html.

39. Carol Goodson, "I Have Seen the Future, and It Is Us!" Journal of Library Services for Distance Education, 1, no. 1 (Aug. 1997). Accessed Feb. 1, 2000, www.westga.edu/ library/jlsde/ jlsde1.1.html.

40. Laura Davidson, "Starting a New Service to Distributed Learners," Journal of Library Services for Distance Education 2, no. 1 (July 1999). Accessed Feb. 1, 2000, www.westga.edu/ library/ jlsde/jlsde2.1.html.

41. Abbot, "Maine College Cyber-Programs Offered Internationally."

42. Ashton, "Piloting Online Professional Development for Networked Learner Support."

43. Orr and Appleton, "New Opportunities for Remote Students."

44. Gloria Lebowitz, "After the Millennium: Library Services to Distance Education," Journal of Library Services for Distance Education 1, no. 1 (Aug. 1997). Accessed Feb. 1, 2000, www.westga.edu/ library/jlsde/jlsde1.1.html. 
45. Heller-Ross, "Library Support for Distance Learning Programs."

46. Stephens and Unwin, "The Heart of the Matter."

47. Maryhelen Jones, "High Five for the Next Five: Librarians and Distance Education," Journal of Library Services for Distance Education 1, no. 1 (Aug. 1997). Accessed Feb. 1, 2000, www.westga.edu/ library/jlsde/jlsde1.1.html.

48. Cesar Caballero and Henry T. Ingle, "Thousands Still Shoeless: Developing Library Services in Support of Distance Education: A Case Study," Journal of Library Services for Distance Education 1, no. 2 (Aug. 1997). Accessed Feb. 1, 2000, www.westga.edu/ library/jlsde/ jlsde1.2.html.

49. Kitti Canepi, "Implementing Library Services for an Off-Campus Site: Evolution, Not Revolution," Journal of Library Services for Distance Education 2, no. 1 (July 1999). Accessed Feb. 1, 2000, www.westga.edu/ library/jlsde/jlsde2.1.html.

50. Judith Clark and Ron Store, "Flexible Learning and the Library: The Challenge," Journal of Library Services for Distance Education 1, no. 2 (June 1998). Accessed Feb. 1, 2000, www.westga.edu/ library/jlsde/jlsde1.2.html.

51. Angela Lee, "Delivering Library Services at a Distance: A Case Study at the University of Washington," Journal of Library Services for Distance Education 2, no. 1 (July 1999). Accessed Feb. 1, 2000, www.westga.edu/ library/jlsde/jlsde2.1.html.

52. Beagle, "Asynchronous Delivery Support for Distance Learning."

53. Heller-Ross, "Library Support for Distance Learning Programs."

54. Ashton, "Piloting Online Professional Development for Networked Learner Support."

55. Adams, "The Future of Library Services for Distance Education."

56. Peter Brophy, "Off-Campus Library Services: A Model for the Future," Journal of Library Services for Distance Education 1, no. 1 (Aug. 1997). Accessed Feb. 1, 2000, www.westga.edu/ library/jlsde/jlsde1.1.html.

57. Jones, "High Five for the Next Five."

58. Marie Kascus, "Converging Vision of Library Service for Off-Campus/Distance Education," Journal of Library Services for Distance Education 1, no. 1 (Aug. 1997). Accessed Feb. 1, 2000, www.westga.edu/ library/jlsde/jlsde1.1.html.

59. Lee, "Delivering Library Services at a Distance."

60. Caballero and Ingle, "Thousands Still Shoeless."

61. Heller-Ross, "Library Support for Distance Learning Programs."

62. Abbot, "Maine College Cyber-Programs Offered Internationally."

63. Brophy, "Off-Campus Library Services."

64. Tony Cavanagh, "Library Services for Off-Campus Students: at the Crossroads?" Journal of Library Services for Distance Education 1, no. 1 (Aug. 1997). Accessed Feb. 1, 2000, www.westga.edu/ library/jlsde/jlsde1.1.html.

65. Jones, "High Five for the Next Five."

66. Adams, "The Future of Library Services for Distance Education."

67. Alexander L. Slade, "Some Observations on the Future of Library Services for Off-Campus and Distance Education," Journal of Library Services for Distance Education 1, no. 1 (Aug. 1997). Accessed Feb. 1, 2000, www.westga.edu/ library/jlsde/jlsde1.1.html.

68. Stephens and Unwin, "The Heart of the Matter."

69. Ashton, "Piloting Online Professional Development for Networked Learner Support."

70. Clark and Store, "Flexible Learning and the Library." 